\title{
METHODOLOGY OF ESTIMATION OF ENERGY RESERVES AND ENERGY EFFICIENCY OF THE HOUSING FUND OF UKRAINE
}

In this article for the first time, a two-level system of economic and mathematical models has been built, taking into account economic, technical and social indicators, which allows predicting and optimizing the level of energy consumption. The application of this system provides for the presence of input values of independent variables, obtained by expert means or using trend dependencies. Based on the system of economic and mathematical models, an optimizing function for the minimum consumption of energy resources per $1 \mathrm{sq} . \mathrm{m}$. of living space and the optimization function for the minimum consumption of energy resources per person have been obtained. It is proved that the proposed economic-mathematical models characterize the controlled processes of energy consumption and their interconnection. The article compares the calculated indicators of the optimal energy consumption with the actual statistical data for the period, allows us to affirm the existence of a significant energy saving potential in the housing stock of Ukraine.

Keywords: energy efficiency, economic and mathematical modeling, optimization function, minimization of energy consumption, housing stock.

DOI: $10.21272 / \mathrm{mmi} .2018 .1-30$

Statement of the problem. In the modern world, availability and access of fuel and energy resources, uninterrupted of supply and efficiency of their use largely determine the stability and pace of any country development. The problem of increasing of the level of energy efficiency is not new as for Ukraine and for each region in particular.

Ukrainian industry and the domestic sector are now extremely energy-intensive, and because of the situation our country is dependent on energy resources that extracted abroad and it is not able to significantly influence on price level of imported energy resources and substantially diversify its supply, primarily this concerns for natural gas. This is reflected in the economic development of each of sectors of the economy, and on the cost of production, and on the living standard for people who are forced to pay more for heating and utilities every year.

The current situation raises the issue of saving energy resources in one row with key issues of the state's economic security, and the introduction of energy saving measures at all levels of the economic mechanism determines the priority task, the timing and quality of which depends the functioning and even survival of the entire country.

The search of the ways which increase the effective energy consumption in the housing and communal services sector (Housing Utilities) of Ukraine should be done taking into account the real state of the housing stock as well as above-mentioned reasons. It is established that more than $30 \%$ of the total fuel consumption in Ukraine in the overall structure of energy costs falls on the housing and communal sector that is one of the largest consumers of thermal energy.

The prerequisites for purposeful development of the organizational and technological potential of energy saving and energy efficiency improvement of Ukraine's housing stock redirect by rising energy prices on energy resources, physical and moral depreciation of thermal and electric networks, machinery, 
equipment, buildings. Considerable factors of increasing energy efficiency should be attributed to the fact that Ukraine, being integrated into the world economy, must observe the international economic principles, one of which is the growth of energy efficiency.

The issue of energy efficiency and the economical use of energy resources has long been a matter of urgency for many countries around the world. The increasing number of them tries to solve the problem of efficient use of energy resources through the introduction of new technologies. And Ukraine, in terms of its own capabilities, does not stand aside these tendencies.

Thus, Ukraine has taken a clear course towards achieving energy independence by adopting the National Energy Efficiency Action Plan for the period up to 2020, which aims to reduce the final domestic energy consumption by $9 \%$ in 2020 or by 6.5 million tons in the year. In 2017 , is expected to achieve an intermediate energy saving indicator of $5 \%$. Achieving such indicators is possible in the way of implementing appropriate measures in several directions at the same time: at the domestic level, in industry, transport and services.

For the domestic sector, ways of improving energy efficiency such as: introduction of $100 \%$ commercial accounting for energy use; improvement of construction norms and standards (in particular, provision of an annual increase in the number of newly built buildings with close to zero energy consumption); introduction of energy audit and certification schemes, energy labeling and indication of information on the amount of energy consumption for energy consuming devices; introduction of minimum energy efficiency standards; financial support of households for implementation of measures to increase energy efficiency of residential buildings; conducting information campaigns to ensure energy savings due to changes in the behavior of energy consumers and more extensive measures [1].

Energy saving in our country has a higher priority compared to the modernization of power engineering, so it should be considered as an additional, quite real and effective "source" of fuel and energy resources. Given that a significant part of the expenditures in the budget sector of cities and other settlements is related to the cost of utilities, the issue of improving their energy efficiency is extremely relevant.

The previous studies made it possible to identify energy saving reserves in this sector, which, according to overall estimates of scientists and practitioners, varies from $50 \%$ to $70 \%$ of the current level of energy consumption.

During 2016, the population and business actively participated in energy efficiency activities. In particular, thanks to the state support, people actively modernized (equipping with accounting tools of energy consumption, insulation, etc.) of residential premises, and business massively switched to energysaving technologies. This indicates the beginning of the formation of a new culture of production and consumption of energy resources in the country.

An overview of recent research sources and publications. A wide range of issues related to the development of energy, in particular to expand the use of renewable energy sources, minimize the volumes and cost of energy used to provide services to improve energy efficiency, are considered by M. Radovanovic (Golusin), S. Popov, S. Dodich (2013) [2]. The study of the difference in energy efficiency depending on the group of consumers and its type was reflected in the work of K. Gillingham, K. Palmer (2014) [3]. An analysis of the world's energy use, incentives and tariffs for utilities, as well as energy management programs for buildings is presented in the works of K. Smith, K. Parmenter (2015) [4]. The potential of the utilities market, the role and tasks of its players, the modeling of demand and the forecasting of energy prices have been studied by F. Sioshansi (2016) [5]. Strategies for managing energy consumption for efficient use of resources in the conditions of technological progress are given in the works of G. Kayakutlu, E. Mercier-Laurent (2016) [6].

R. Podolets (2006) considered in his writings the problems of using mathematical models to determine the optimal directions and volumes of investments in the energy industry [7]. In the works of V. Kapustyan, M. Chepelev (2014) was proposed an approach to study adequacy of economic and mathematical tools 
which used for the assessment of impacts of subsidies in the energy sector of the economy or housing [8]. The issues of development of economic-mathematical models of the dynamics of the changing state of the housing market were studied by Galchinskiy L. (2010) [9]. The technical condition of the housing stock of Ukraine was investigated by M. Sukhonos, T. Molodchenko (2014) [10]. The problem of energy saving in the housing fund was considered by V. Volkov (2013) [11]. However, there is an open question of optimization of the energy efficiency indicators of the existing housing stock, including with use of economic-mathematical methods.

The main purpose of this work is to develop a methodology for estimating energy efficiency indicators of the existing housing stock, based on building an optimization economic-mathematical model for determining energy consumption reserves.

The main results of the research. The analysis of theoretical developments and the current regulatory framework for assessing the energy efficiency of consumers use various indicators, namely: physical and technical (consumption, transportation and storage of FER), socio-energy (level of energy and economic expenditures), economic-energy (the ratio between economic performance and relevant expenditure FER).

As a rule, the energy efficiency indicators are the specific values presented as a ratio of energy consumption (measured in energy units - kilowatt-hours, joules, tons of oil equivalent, etc.) to activity data (expressed in natural units - per unit of production, floor space, per capita, etc.):

$$
\text { The level of energy efficiency }=\frac{\text { Energy consumption }}{\text { Operations }}
$$

The energy efficiency indicators are calculated at the level of end-use or economic activity, or even at the level of equipment energy consumption. For example, within the residential sector energy consumption for heating per unit area is a measure of efficiency at the level of final consumption. The consumption of household technical devices is an indicator of energy efficiency at the level of equipment energy consumption [12].

However, the existing methods of assessing the energy efficiency of the housing sector do not take into account several key positions: the technical condition of the housing stock and its available reserves for optimizing energy consumption, the level of household income and their real opportunities to participate in state and regional energy efficiency programs; introduction of a justified tariff policy for energy resources and an appropriate social protection policy and the amount of social payments (subsidies). This makes it impossible to effectively implement state and regional energy-saving programs.

In view of the foregoing, it is advisable to carry out an assessment of energy consumption reserves and the possibilities for efficient consumption of energy resources in the housing stock of Ukraine, taking into account economic, technical and social indicators. This allows us to forecast and optimize the level of energy consumption.

To reveal the energy saving reserves of the housing stock (increasing its energy efficiency), the materials of the State Statistics Service of Ukraine were used for the period from 2009-2015 [13], on the basis of which the basic indicators of energy efficiency of the existing housing stock were determined (Table 1).

Table 1 - The basic indicators of energy efficiency of the existing housing stock (author's elaboration)

\begin{tabular}{|c|c|c|}
\hline Indicator & Energy consumption & Operations \\
\hline $\begin{array}{c}\text { Consumption of energy resources for } \\
\text { 1sq.m. of residential square toe/sq. } \mathrm{m} .\end{array}$ & $\begin{array}{c}\text { Final consumption household } \\
\text { sector total, thousand toe }\left(\mathrm{Y}_{1}\right)\end{array}$ & $\begin{array}{c}\text { Residential area of housing apartments } \\
\text { (municipal settlements and rural locality), } \\
\text { thousand } \mathrm{m}^{2}\left(\mathrm{Y}_{2}\right)\end{array}$ \\
\hline $\begin{array}{c}\text { Energy resources consumption per } \\
\text { capita, toe/person }\end{array}$ & $\begin{array}{c}\text { Final consumption household } \\
\text { sector total, thousand toe }\left(\mathrm{Y}_{1}\right)\end{array}$ & The existing population, thousand $\left(\mathrm{Y}_{3}\right)$ \\
\hline
\end{tabular}


Data for 2016 was obtained by predicting by the method of analytical representation of the trend (linear, exponential, power-law dependence) and the method of least squares (polynomial and exponential dependence of the second order). For each model, the adequacy check indicators were calculated: the correlation coefficient and the F-statistic. It is established that all the selected models are adequate.

Given the complexity and diversity of the housing stock and to implement a more detailed assessment of its efficiency is proposed to consider it as a system, and accordingly, to apply such a scientific approach, like a decomposition that allows us to consider any studying system as a complex, consisting of separate interconnected subsystems, within which, in turn, can be allocated to subsystems of lower rank.

Factors influencing the components of energy efficiency indicators (Y1, Y2, Y3) were selected using correlation regression analysis. Evaluation of the importance of factors affecting the energy efficiency indicators of the existing housing stock is a prerequisite for building a system of econometric models. The groups of factors of influence on the level of energy consumption of the existing housing stock are: 1) economic (level of income and household consumption expenditures, energy prices, expenditures on maintenance of housing and communal services from state and local budgets, expenditures and major repairs of buildings) 2) technical (the level of provision of single-family houses with heating, the disposal and receipt of the total area of residential premises, the state of the housing stock (emergency, dilapidated)) 3) social (level of remuneration, pension provision on average per household and the amount of subsidies and privileges for housing and communal services).

Taking into account the influence of these factors on the energy efficiency indicators of the existing housing stock allows us to obtain a more accurate estimate of the energy efficiency of the country's housing stock and to determine the reserves of energy consumption.

Economic-mathematical modeling of energy efficiency indicators of the existing housing stock includes the construction of a system of econometric models in order to obtain the optimization function of energy consumption. The construction and implementation of econometric models is performed in the STATISTICA 8.0 application package (a universal integrated system designed for statistical analysis and data processing) an example is presented in the article [14].

As a result of this research, the hierarchical tree of logical inference was built to represent the obtained results in general form (Fig. 1-2):

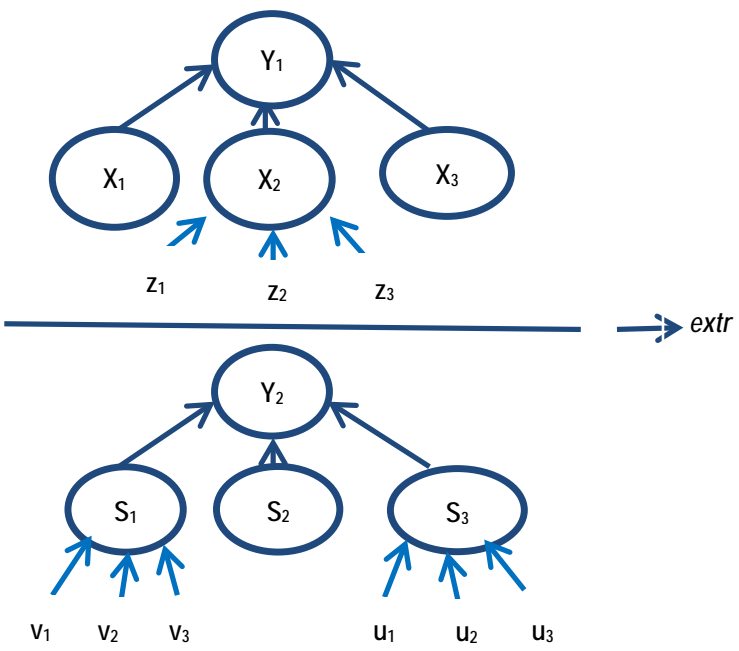

Figure 1 - Hierarchical tree logical inference to optimize energy consumption indicator per 1 sq. $\mathrm{m}$. of living space (author's elaboration) 

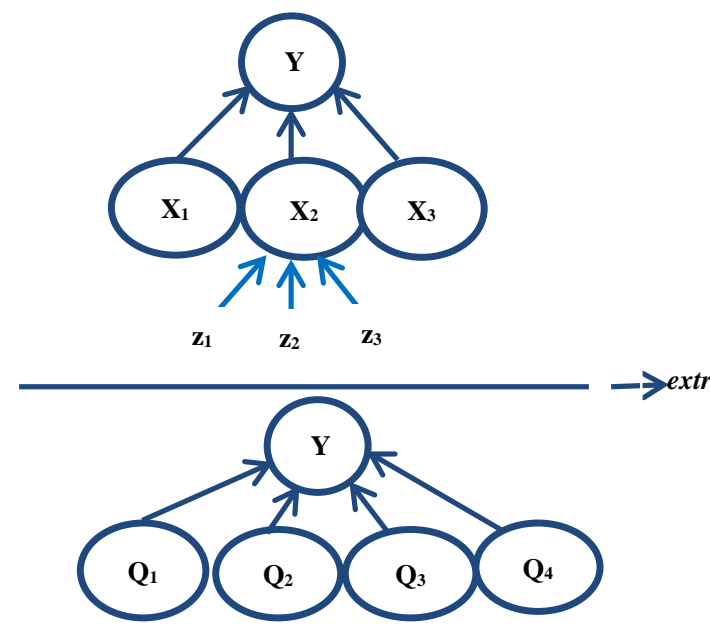

Figure 2 - Hierarchical tree logical inference to optimize energy consumption indicator per capita (author's elaboration)

The elements of the tree are interpreted as follows: arcs, leaving the vertices are the effective characteristics; arc incoming in the vertices are the factors of influence; the vertices are the economic-mathematical model.

Hierarchical tree (Fig. 1) corresponds to the objective function and system constraints (2):

$$
\frac{Y_{1}}{Y_{2}}=\frac{a_{0}+a_{1} X_{1}+a_{2} X_{2}+a_{3} X_{3}}{b_{0}+b_{1} S_{1}+b_{2} S_{2}+b_{3} S_{3}} \rightarrow \min ,\left\{\begin{array}{l}
X_{2}=c_{0}+c_{1} z_{1}+c_{2} z_{2}+c_{3} z_{3} \\
S_{1}=\delta_{0}+\delta_{1} v_{1}+\delta_{2} v_{2}+\delta_{3} v_{3} \\
S_{3}=\beta_{0}+\beta_{1} u_{1}+\beta_{2} u_{2}+\beta_{3} u_{3}
\end{array}\right.
$$

Hierarchical tree (Fig. 2) corresponds to the objective function (3):

$$
\frac{Y_{1}}{Y_{3}}=\frac{a_{0}+a_{1} X_{1}+a_{2} X_{2}+a_{3} X_{3}}{\varphi_{0}+\varphi_{1} Q_{1}+\varphi_{2} Q_{2}+\varphi_{3} Q_{3}+\varphi_{4} Q_{4}} \rightarrow \min
$$

Schematically, a two-level system of econometric models is shown in Fig. 3.

The application of this system assumes the presence of input values $z_{1}, z_{2}, z_{3} ; v_{1}, v_{2}, v_{3} ; u_{1}, u_{2}, u_{3}$, obtained expertly or using trend dependencies. It is proved that the proposed economic-mathematical models characterize the controlled processes of energy consumption and their interconnection. Instruments of state regulation, management decisions of local self-government, as well as at the level of management of housing and communal services enterprises, can be improved.

Received optimization function of the minimum energy consumption per 1 sq. m. of residential space on the basis of economic-mathematical models (2) (4) with the following restrictions:

$$
\begin{array}{ccc}
\frac{Y_{1}}{Y_{2}}=\frac{a_{0}+a_{1} X_{1}+a_{2}\left(c_{0}+c_{1} z_{1}+c_{2} z_{2}+c_{3} z_{3}\right)+a_{3} X_{3}}{b_{0}+b_{1}\left(\delta_{0}+\delta_{1} v_{1}+\delta_{2} v_{2}+\delta_{3} v_{3}\right)+b_{2} S_{2}+b_{3}\left(\beta_{0}+\beta_{1} u_{1}+\beta_{2} u_{2}+\beta_{3} u_{3}\right)} \rightarrow \min \\
10721 \geq X_{1} \geq 12265 ; & 798,9 \geq S_{1} \geq 1762,77 ; & 2415,13 \geq z_{1} \geq 4782,65 ; \\
258,89 \geq X_{2} \geq 570,0 ; & 6055,6 \geq S_{2} \geq 34458 ; & 17,8 \geq z_{2} \geq 78,19 ; \\
100,3 \geq X_{3} \geq 215,8 ; & 11693,9 \geq S_{3} \geq 41128 ; & 2669,96 \geq z_{3} \geq 4946,09 ; \\
207619,9 \geq v_{1} \geq 405727,3 ; & 1014 \geq u_{2} \geq 1184,48 ; \\
64,92 \geq v_{2} \geq 844,4 ; & 5092,16 \geq u_{3} \geq 8010,49 ;
\end{array}
$$


Розділ 5 Екологічний маркетинг та менеджмент

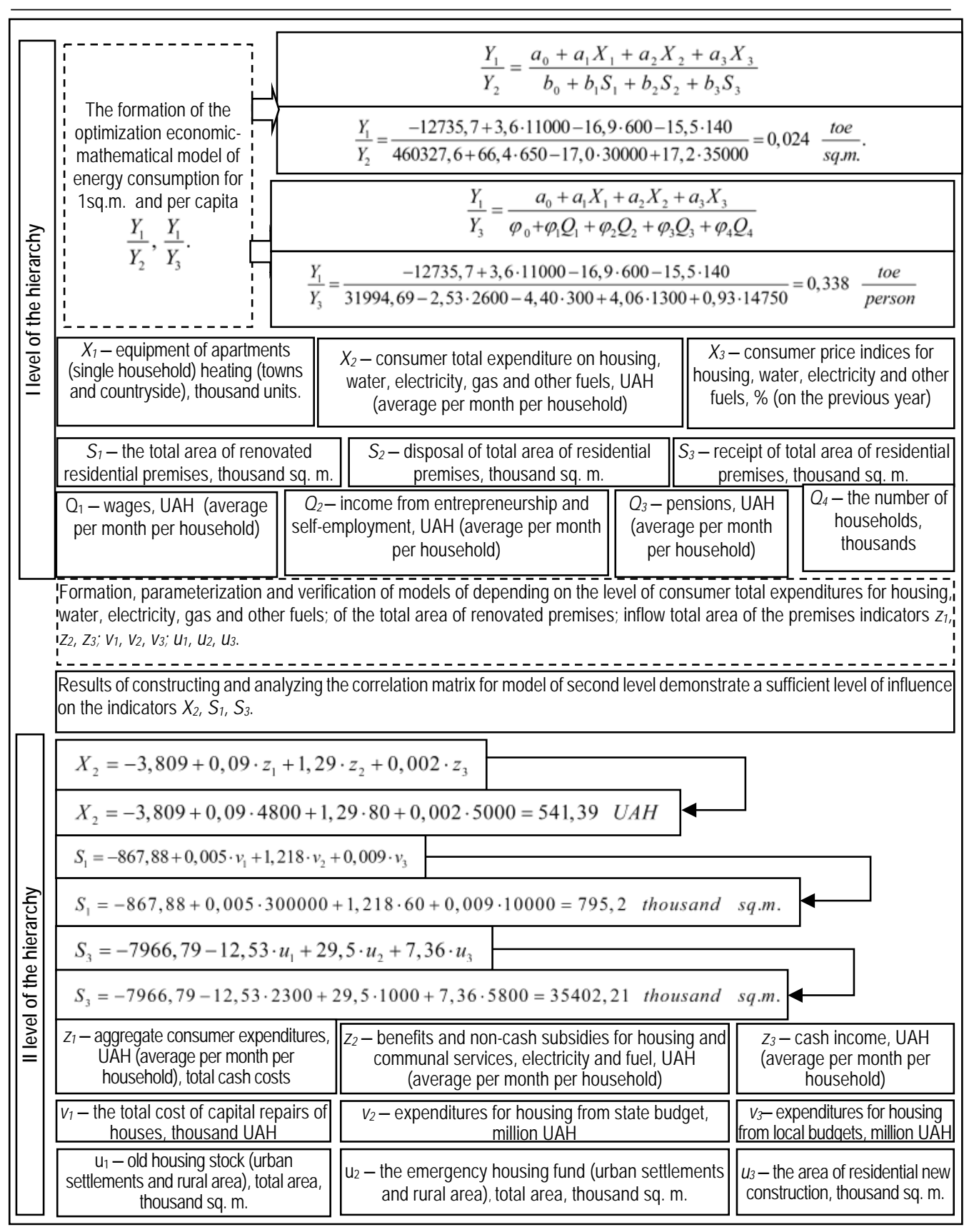

Figure 3 - The two-level system of economic-mathematical models (author's elaboration)

The results of calculations of minimal energy consumption for 1 sq.m. of living space in Ukraine is 0,014 toe/sq.m. 
Based on economic-mathematical model (3) it was received optimization function of the minimum energy consumption per person (5) with the following restrictions:

$$
\begin{array}{rcc}
\frac{Y_{1}}{Y_{3}}=\frac{a_{0}+a_{1} X_{1}+a_{2}\left(c_{0}+c_{1} z_{1}+c_{2} Z_{2}+c_{3} Z_{3}\right)+a_{3} X_{3}}{\varphi_{0}+\varphi_{1} Q_{1}+\varphi_{2} Q_{2}+\varphi_{3} Q_{3}+\varphi_{4} Q_{4}} & \\
& 1446,4 \geq Q_{1} \geq 2263,9 ; & \min \\
10721 \geq X_{1} \geq 12265 ; & 156,24 \geq Q_{2} \geq 330,1 ; & 2415,13 \geq z_{1} \geq 4782,65 ; \\
258,89 \geq X_{2} \geq 570,0 ; & 597,24 \geq Q_{3} \geq 1239,08 ; & 17,8 \geq z_{2} \geq 78,19 ; \\
100,3 \geq X_{3} \geq 215,8 ; & 14455,5 \geq Q_{3} \geq 17096,8 ; & 2669,96 \geq z_{3} \geq 4946,09 ;
\end{array}
$$

The results of calculations of minimal energy consumption per capita in Ukraine is 0,273 toe/person.

Fig. 4 shows the dynamics of the energy efficiency of housing stock in $2009-2016$ and the best values of energy consumption in Ukraine.

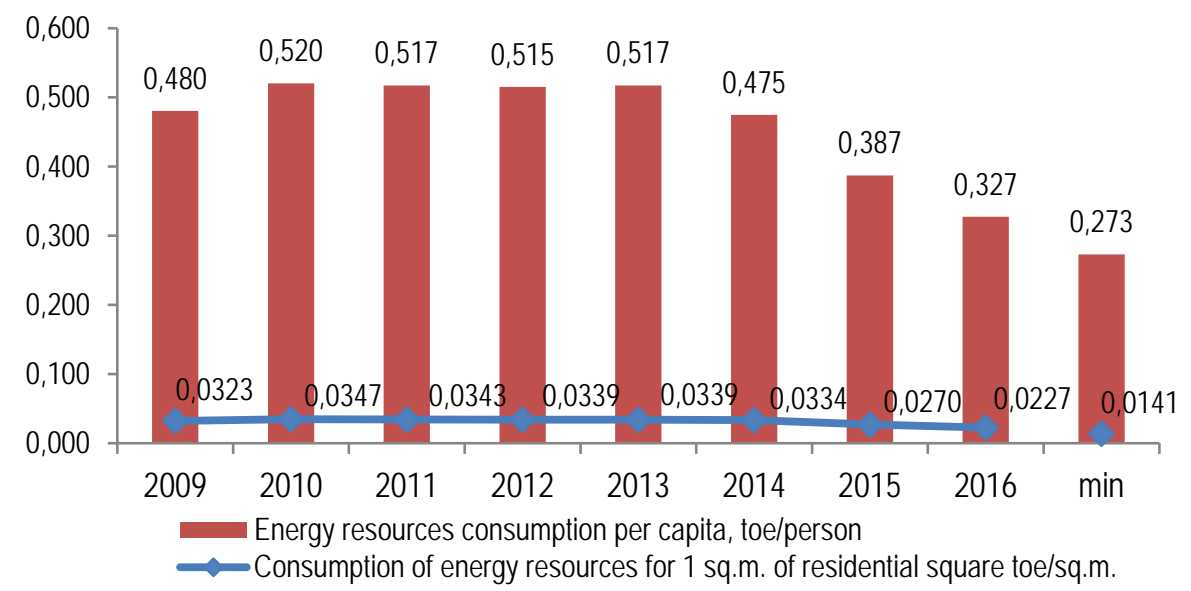

Figure 4 - The dynamics of indicators of the energy efficiency of housing stock in Ukraine (author's elaboration)

Resulting in optimal energy consumption per $1 \mathrm{sq}$. $\mathrm{m}$ of living space in Ukraine is $37.9 \%$ lower than actual, and the index of the optimal energy consumption per person in Ukraine is $16.5 \%$ lower than the real one, this indicates that the existing housing stock has significant potential for energy savings.

In this regard, in the sphere of exploitation of housing stock, priority is given to ensuring minimum energy consumption due to the implementation of a complex of energy-saving measures during the life cycle of construction objects. However, the life cycle of construction products is quite long. During it, there may be some changes in construction technologies, production technologies and energy consumption, in macroeconomic processes.

Taking into account these changes, along with a number of architectural, organizational, technological, and economic factors, will provide an adequate definition and justification of the economic efficiency of energy saving measures with the complex reconstruction of the housing stock and secondary building of residential neighborhoods.

The solution of the energy efficiency problem in the housing stock is a significant reserve of the economic potential growth in this area, as the reconstruction and overhaul (thermo-modernization) of the housing stock will increase the business activity in the industry, will improve the living conditions of the population, will contribute increasing of employment as a result of infrastructure development in this area 
(energy audit, energy service companies), will reduce the dependence on exhausted resources.

The main constraining factor of investment activity in the sphere of energy saving is the chronic lack of funds from the state and local budgets. Therefore, to finance projects in the field of energy saving, it is necessary to use different forms of interaction between state, international and market institutions, taking into account the current situation on the domestic financial market and the prospects for its development.

An important role in the process of investing in energy saving should be played by additional resources that arise in the economy as a result of its market transformation (performance contracting, project and debt financing, revolving funds, leasing of energy equipment, energy saving funds at different levels of management, partnership funds, venture capital funds, funds of international organizations).

However, the problem of increasing energy efficiency indicators cannot be solved without taking into account the specific features of the socio-economic development of regions in which a certain energysaving infrastructure is created. At the same time, despite the presence of a numerous of achievements in the area of increasing energy efficiency indicators just at the regional level, practically does not use a systematic approach to the development of energy-saving policies and strategies for managing of energy efficiency in the economy.

The introduction and use of resource-saving and energy-saving technologies should be related to the strategies of socio-economic development of Ukraine and its regions and considered in developing relevant program documents.

Conclusions and further research directions. Thus, a methodical approach was developed to assess the energy efficiency of the existing housing stock in order to identify energy consumption reserves, which makes it possible to determine the appropriate directions for the formation of state and regional energy saving policies and improving the energy efficiency of housing in Ukraine; legislative resolution of the issue of improving the energy efficiency of buildings; carrying out measures to renovate and improve the quality of housing stock and increase its energy efficiency; improving the mechanism for stimulating the introduction of energy-saving technologies and creating attractive conditions for the implementation of investment projects in the housing sector, informing the general public and forming a conscious attitude to the need for efficient and economical consumption of fuel and energy resources in society.

The expected benefits of energy efficiency for Ukraine is the reduction of energy consumption and dependence on their import, the growth of welfare of population, reducing investment in energy infrastructure and improvement of the ecological situation after reduction of greenhouse gases. The proposed method can be applied to determine the energy efficiency indicators at the regional level.

1. Національний план дій з енергоефективності на період до 2020 року [Електронний ресурс]. - Режим доступу: http://zakon5.rada.gov.ua/laws/show/n0001824-15/paran2\#n2.

2. Golusin M. Sustainable Energy Management / M. Golusin, S. Popov, S. Dodic. - Elsevier Inc., 2013. - 391 p.

3. Gillingham K. Bridging the energy efficiency gap: Policy insights from economic theory and empirical evidence $/$ K. Gillingham, R. Palmer // Journal of Review of Environmental Economics and Policy. - 2014. - 8(1). - P. 18-38.

4. Smith G. Energy Management Principles (2nded.) / G. Smith, K. Parmenter. - Elsevier Inc., 2015. - 397 p.

5. Sioshansi F.P. Future of Utilities - Utilities of the Future: How Technological Innovations in Distributed Energy Resources Will Reshape the Electric Power Sector (1st ed.). / F.P. Sioshansi. - Elsevier Inc., 2016. - 492 p.

6. Kayakutu G. Intelligence in Energy (1st ed.). / G. Kayakutu, E. Mercier-Laurent. - Elsevier Inc., 2016. - 252 p.

7. Подолець Р.3. Енергетичне моделювання: іноземний досвід і напрями перспективних досліджень в Україні / Р.3. Подолець // Економіка і прогнозування. - 2006. - № 1. -С. 126-140.

8. Капустян В.О. Економіко-математичне моделювання наслідків енергетичних субсидій: принцип адекватності / В.О. Капустян, М.Г. Чепелєв // Економічний аналіз: зб. наук. праць. - 2014. - Том 15. -№1. -С. 86-100.

9. ГальчинськийЛ.Ю. Економіко-математичне моделювання динаміки зміни стану ринку будівництва в Україні / Л.Ю. Гальчинський, Ю.С. Станіславчук // Економічний вісник НТУУ «КПІ». - Київ: НТУУ «КП|». - 2010. - № 7. - С. 246 -249.

10. Сухонос М.К. Аналіз технічного стану житлового фонду України та пропозиції щодо його оцінки / М.К. Сухонос, Т.Г. Молодченко, В.М. Прасол // Економічний вісник Донбасу. - 2014. - №1 (35). - С.51-55.

11. Волков В.П. Проблеми енергозбереження в житловому фонді / В.П. Волков // Економічний вісник університету. 2013. - Вип. 20(1). - С.83-90. 
О.В. Комеліна, С.А. Щербініна. Методика оцінки резервів енергоспоживання та енергоефективності житлового фонду України

12. Site of International Energy Agency. Energy Efficiency Indicators: Fundamentals on Statistics [Electronic resource]. - Mode access: http://www.iea.org/publications/freepublications/publication/IEA EnergyEfficiencylndicatorsFundamentalsonStatistics.pdf.

13. Сайт Державної служби статистики України [Електронний ресурс] - Режим доступу: http://www.ukrstat.gov.ual.

14. Komelina O.V. Economic-mathematical modeling of the energy efficiency indicators of existing housing stock / O.V. Komelina, S.A. Shcherbinina, K.I. Serdyk // Economics and region. - 2016. - 5(60). - P.111-117.

1. Natsionalnyi plan z enerhoefektyvnosti na period do 2020 roku [National Action Plan for Energy Efficiency until 2020] (n.d.) zakon5.rada.gov.ua. Retrieved from http://zakon5.rada.gov.ua/laws/show/n0001824-15/paran2\#n2 [in Ukrainian].

2. Radovanovic (Golusin), M., \& Popov, S., \& Dodic, S. (2013). Sustainable Energy Management (1st ed.). USA: Elsevier

3. Gillingham, K., \& Palmer, R. (2014). Bridging the energy efficiency gap: Policy insights from economic theory and empirical evidence. Journal of Review of Environmental Economics and Policy, 8(1), 18-38.

4. Smith, G., \& Parmenter, K. (2015). Energy Management Principles (2nd ed.). USA: Elsevier.

5. Sioshansi, F.P. (2016). Future of Utilities - Utilities of the Future: How Technological Innovations in Distributed Energy Resources Will Reshape the Electric Power Sector (1st ed.). USA: Elsevier.

6. Kayakutu, G., \& Mercier-Laurent, E. (2016). Intelligence in Energy (1st ed.). USA: Elsevier.

7. Podolets, R.Z. (2006). Enerhetychne modeliuvannia: inozemnyi dosvid i napriamy perspektyvnykh doslidzhen v Ukrain [Energy modeling: international experience and areas of promising research in Ukraine]. Ekonomika i prohnozuvannia - Economics and forecasting, 1, 126-140 [in Ukrainian].

8. Kapustian, V.O., \& Chepeliev, M.H. (2014). Ekonomiko-matematychne modeliuvannia naslidkiv enerhetychnykh subsydii: pryntsyp adekvatnosti [Economic-mathematical modeling of consequences of energy subsidies: the principle of adequacy] Ekonomichnyi analiz: zb. nauk. prats - Economic analysis: coll. sciences works, 1, 86-100 [in Ukrainian].

9. Halchynskyi, L.Yu., \& Stanislavchuk, Yu.S. (2010). Ekonomiko-matematychne modeliuvannia dynamiky zminy stanu rynku budivnytstva $\vee$ Ukraini [Economic mathematical modeling of the dynamics of the changing state of the construction market in Ukraine]. Ekonomichnyi visnyk NTUU "KPI" - Economic Bulletin of NTUU "KPI", 7, 246-249 [in Ukrainian]

10. Sukhonos, M.K., \& Molodchenko, T.H., \& Prasol, V.M. (2014). Analiz tekhnichnoho stanu zhytlovoho fondu Ukrainy ta propozytsii shchodo yoho otsinky [Analysis of the technical condition of the housing stock of Ukraine and proposals for its evaluation]. Ekonomichnyi visnyk Donbasu - Economic Bulletin of Donbas, 1 (35), 51-55 [in Ukrainian].

11. Volkov, V.P. (2013). Problemy enerhozberezhennia v zhytlovomu fondi [Problems of energy saving in the housing fund] Economichnyi vicnyk universytetu - The Economic Bulletin of the University, 20(1), 83-90 [in Ukrainian].

12. International Energy Agency (n.d.). Energy Efficiency Indicators: Fundamentals on Statistics. iea.org. Retrieved from http://www.iea.org/publications/freepublications/publication/IEA_EnergyEfficiencyIndicatorsFundamentalsonStatistics.pdf.

13. Sait Derzhavnoi cluzhby statystyky Ukrainy [Site of state statistics service of Ukraine] (n.d.). ukrstat.gov.ua. Retrieved from http://www.ukrstat.gov.ua [in Ukrainian].

14. Komelina, O.V., \& Shcherbinina, S.A., \& Serdyuk, K.I. (2016). Economic-mathematical modeling of the energy efficiency indicators of existing housing stock. Economics and region 5(60), 111-117.

О.В. Комеліна, д-р екон. наук, професор кафедри менеджменту і логістики, Полтавський національний технічний університет імені Юрія Кондратюка (м. Полтава, Україна);

С.А. Щербініна, старший викладач кафедри економічної кібернетики, Полтавський національний технічний університет імені Юрія Кондратюка (м. Полтава, Україна)

Методика оцінки резервів енергоспоживання та енергоефективності житлового фонду України

У статті досліджено показники ефьективності енергоспоживання житлового фонду України в иілому. Розроблено дворівневу систему економіко-математичних моделей для побудови оптимізаційної ффункції мінімізації споживання енергоресурсів. здійснено порівняння розрахункових показників оптимального енергоспоживання до фактичних статистичних даних за період, що дозволяє стверджувати про існування значного потенціалу енергозбереження у житловому фонді України.

Ключові слова: енергоефективність, економіко-математичне моделювання, оптимізаційна функція, мінімізація енергоспоживання, житловий фонд.

О.В. Комелина, д-р экон. наук, профрессор кафедры менеджмента и логистики, Полтавский национальный технический университет имени Юрия Кондратюка (г. Полтава, Украина);

С.А. Щербинина, старший преподаватель кафедры экономической кибернетики, Полтавский национальный технический университет имени Юрия Кондратюка (г. Полтава, Украина)

Методика оценки резервов энергопотребления и энергоэффективности жилого фонда Украины

В статье исследованы показатели эфффективности энергопотребления жилищного фонда Украины в иелом. Разработана двухуровневая система экономико-математических моделей для построения оптимизационной фуннкци минимизации потребления энергоресурсов. Осуществлено сравнение расчетных показателей оптимального энергопотребления к фактическим статистическим данным за период, что позволяет утверждать о существовании значительного потенциала энергосбережения в жилищном фонде Украины.

Ключевые слова: энергоэффективность, экономико-математическое моделирование, оптимизационная функция минимизация энергопотребления, жилищный фонд.

Отримано 07.06.2017 p. 